\title{
Plant-Based Fertilizer for Organic Production
}

\author{
J. Nygaard Sørensen and K. Thorup-Kristensen \\ Department of Horticulture \\ Faculty of Agricultural Sciences, Aarhus University \\ Aarslev \\ Denmark
}

Keywords: green manure, vegetable crops, organic fertilizer, nitrogen, phosphorus, potassium, sulphur, boron

\begin{abstract}
A wide range of potential green-manure crops were tested for their productivity and concentration of plant nutrients, especially $N, P, K, S$ and $B$. Selected green-manure crops were harvested at several developmental stages. Fresh wet, ensiled, and dried green manures were tested in pot and field experiments with several vegetable crops. The results showed that the plant species garden sorrel, dyer's woad, and fodder radish had high $P$ concentrations, and that cruciferous crops like dyer's woad and fodder radish had high $\mathbf{S}$ concentrations. Dyer's woad, salad burnet, and stinging nettle showed high concentration of $B$, whereas species like dandelion, chicory, and garden sorrel showed high concentration of $\mathbf{K}$. In comparing plant species, plants were harvested at a developmental stage corresponding to maximum leaf/stem ratio. The pot experiments showed that green manures with high concentration of $P$ and $S$ increased the nutrient uptake and yield of cauliflower and kale. Although $P$ increased the vegetable production, the results indicate that $S$ was the main limiting growth factor. The field experiments showed that the vegetable production decreased when the $C / N$ ratio of the green manure increased. It was concluded that differences in vegetable production were not due to the amount of $N$ applied, but to the $N$ availability. The overall conclusion of these experiments is that it is possible to produce green manures with high concentrations of $S, K, P$, and $B$, and low $C / N$ ratios, and further, that these properties have great impact on the value of the green manure for vegetable production.
\end{abstract}

\section{INTRODUCTION}

To ensure high yield and quality in organic vegetable production, crops often require additional fertilizer applied during the season. One possibility is to add animal waste slurry. However, due to the risk of microbial contamination from slurry, growers of organic vegetable crops are looking for alternatives. One possibility is to use a green manure.

A fertilizer used for topdressing of vegetable crops needs to fulfil some requirements. First, the fertilizer has to be rich in nutrients. Second, nutrients have to be released rather fast. Finally, a fertilizer has to keep well and has to be easy to handle during transport, crop application and soil incorporation. However, a traditional green manure does not fulfil any of the requirements listed above. A fresh green manure is not storable for more than a few days. It is wet and heavy, and not easy to handle. Further, the fertilizer needs to be decomposed before the nutrients are available for the vegetable plants. This process may take weeks or even months.

The purpose of our work was to develop green manures that fulfil the above listed requirements and to verify their nutrient effects in various vegetable crops. A further objective was to develop green manures with specific high contents of phosphorus (P), potassium (K), sulphur (S), and boron (B) used for top-dressing of nutrient deficient crops. 


\section{MATERIALS AND METHODS}

\section{Potential Green-Manure Crops with Specific Attributes}

In each of three years, 2004-2006, a wide range of potential green-manure crops were tested for their productivity and concentration of plant nutrients. To maximise the concentration of plant nutrients, the green-manure crops were harvested at a developmental stage that results in a high proportion of fresh green leaves in relation to stems. Often this stage corresponds to the initial stage of flowering.

The plant species tested were garden sorrel (Rumex acetosa), dyer's woad (Isatis tinctoria), fodder radish (Raphanus sativus), salad burnet (Sanguisorba minor), stinging nettle (Urtica dioica), dandelion (Taraxacum officinale), lucerne (Medicago sativa), red clover (Trifolium pratense), alsike clover (Trifolium hybridum), yellow sweetclover (Melilotus officinalis), pea (Pisum sativum), yellow lupin (Lupinus luteus), rape (Brassica napus), buckwheat (Fagopyrum esculentum), English plantain, (Plantago lanceolata), evening primrose (Oenothera biennis), chicory (Cichorium intybus), and phacelia (Phacelia tanacetifolia).

At harvest, the fresh weight was determined and the plant material was dried by forced air at $25^{\circ} \mathrm{C}$. The dry material was chopped and plant samples were analysed for $\mathrm{P}$, $\mathrm{K}, \mathrm{S}, \mathrm{B}$, nitrogen $(\mathrm{N})$, and carbon $(\mathrm{C})$.

In pot experiments, the chopped plant material was used as fertilizer for cauliflower (Brassica oleracea botrytis) and kale (Brassica oleracea sabellica), in 2006 and 2007, respectively. The various green manures were applied in equal amounts to all pots. As $\mathrm{N}$ effect was not the issue in these experiments, all treatments received a supraoptimal amount of urea to suppress any $\mathrm{N}$ response. Plants were irrigated with rain water. At harvest of the vegetable crops, the plant production was determined. Plant samples were dried and analysed for N, P, K, S, and B.

\section{Field Tests of Potential Green-Manure Crops}

Green manures for fertilizer experiments located at the Department of Horticulture, Aarslev were produced in spring and dried by forced air at $25^{\circ} \mathrm{C}$. The species garden sorrel, lucerne, and red clover were harvested at several developmental stages, and fodder radish, rape, buckwheat, phacelia, and stinging nettle at a high leaf/stem ratio. The dry material was chopped and plant samples were analysed for $\mathrm{C}, \mathrm{N}$, $\mathrm{P}, \mathrm{K}, \mathrm{S}$, and $\mathrm{B}$.

In the field experiments, the chopped plant material was used as fertilizer for cauliflower in 2005 and 2006, and for kale in 2007. A range of dry green manures with varying $\mathrm{C} / \mathrm{N}$ ratios were applied to the vegetable crops. The amount of $\mathrm{N}$ applied was $160 \mathrm{~kg}$ total $\mathrm{N}$ per ha for all green manures. At harvest of the vegetable crops, the plant production was determined. Plant samples were dried and analysed for N, P, K, S, and B.

Green manures for fertilizer experiments located on vegetable farms were produced by the growers or purchased. Various amounts of fresh, ensiled or dry green manure were applied to leeks (Allium porrum) and celery (Apium graveolens dulce). The amount of nutrients applied with the fertilizer was recorded. Plant production and nutrient concentration were determined at harvest.

\section{RESULTS AND DISCUSSION}

\section{Nutrient Rich Green-Manure Crops}

The screening of potential green-manure crops harvested at a developmental stage corresponding to a high leaf/stem ratio showed that garden sorrel, dyer's woad, and fodder radish have high $\mathrm{P}$ concentration, and that cruciferous crops like dyer's woad and fodder radish have high $\mathrm{S}$ concentration (Table 1). Dyer's woad, salad burnet, and stinging nettle showed high concentration of B, whereas species like dandelion, chicory, and garden sorrel showed high concentration of $\mathrm{K}$.

Variation in nutrient content among plant species is well-known, and also valid for 
green-manure crops. However, within a plant species, the chemical composition is influenced by the developmental stage. Usually, the concentration of $\mathrm{N}$ and other macro nutrients decreases during plant ontogeny due to a dilution effect. In the present experiment, we aimed to sample plants at a stage when the proportion of fresh green leaves in relation to stems was maximized. Often this stage corresponds to the initial stage of flowering. However, in some plant species it is rather difficult to determine the optimum sampling date, and therefore, comparison among plant species is complex in respect to nutrient content.

The pot experiments showed that green manures with high concentration of $\mathrm{P}$ increased the nutrient uptake and yield of cauliflower and kale (Fig. 1). By omitting fodder radish and dyer's woad the $\mathrm{R}^{2}$ was increased to 0.7022 . Although, $\mathrm{P}$ increased the production of kale, the results indicate that $\mathrm{S}$ was the main limiting growth factor. In the present experiment, fodder radish and garden sorrel had low $\mathrm{C} / \mathrm{P}$ ratios, and fodder radish and dyer's woad had low $\mathrm{C} / \mathrm{S}$ ratios. Low $\mathrm{C} / \mathrm{P}$ and $\mathrm{C} / \mathrm{S}$ ratios results in quick release of $\mathrm{P}$ and $\mathrm{S}$, and in increased $\mathrm{P}$ and $\mathrm{S}$ uptake by the vegetable crops.

\section{Field Tests of Potential Green-Manure Crops}

In the field experiments, cauliflower or kale was applied with $160 \mathrm{~kg}$ total $\mathrm{N}$ per ha in several chopped dry green manures with varying $\mathrm{C} / \mathrm{N}$ ratios. For all three experimental years, the non-fertilized vegetable plants produced less. Further, the vegetable production decreased with increasing $\mathrm{C} / \mathrm{N}$ ratio of the green manure (Fig. 2 ). It was concluded that differences in vegetable production were not due to the amount of $\mathrm{N}$ applied, but to the $\mathrm{N}$ availability. Although $\mathrm{N}$ immobilization probably occurred in the present experiments, all green manures resulted in positive net mineralization. The $\mathrm{N}$ immobilization differed among green manures and probably increased at increasing $\mathrm{C} / \mathrm{N}$ ratio after soil incorporation of the green manures. Generally, $\mathrm{C} / \mathrm{N}$ ratios above 18 to 20 result in $\mathrm{N}$ immobilization. In the present experiment, $\mathrm{C} / \mathrm{N}$ ratio above 20 was obtained in late harvested lucerne and garden sorrel.

Non-fertilized plants produced had the highest dry matter content. Application of fodder radish and stinging nettle, which both had a high concentration of $\mathrm{S}$, resulted in a high $\mathrm{S}$ concentration of kale leaves.

On vegetable farms, various amounts of fresh, ensiled or dry green manure were applied to leeks and celery. Increasing amounts of green manure increased the yield of both leeks (Fig. 3) and celery. However, the $\mathrm{C} / \mathrm{N}$ ratio of the green manures determined the yield response, and from these experiments it was concluded that the $\mathrm{C} / \mathrm{N}$ ratio has to be low, and preferably below 12, if a quick response is needed. Further, these field experiments demonstrated the importance of a green manure, which can be stored until it is needed, and which is easy to handle during transport, crop application and soil incorporation.

\section{CONCLUSIONS}

The overall conclusions of these experiments are that it is possible to produce green manures with specific high nutrient concentrations of e.g., S, K, P, and B, and low $\mathrm{C} / \mathrm{N}$ ratios, and further, these properties have great impact on the vegetable yield and quality. 


\section{$\underline{\text { Tables }}$}

Table 1. Concentration of $\mathrm{P}, \mathrm{K}$, and $\mathrm{S}(\%)$ and $\mathrm{B}(\mathrm{ppm})$ in the dry matter of green-manure crops with high nutrient content and of species with less high content.

\begin{tabular}{lccc}
\hline Nutrient & $\begin{array}{c}\text { Plant species with high nutrient } \\
\text { concentration }\end{array}$ & $\begin{array}{c}\text { Concentration } \\
\text { in high-nutrient } \\
\text { plant species }\end{array}$ & $\begin{array}{c}\text { Concentration } \\
\text { in other } \\
\text { species tested }\end{array}$ \\
\hline P & Garden sorrel, dyer's woad, fodder radish & $0.4-0.5$ & $0.2-0.4$ \\
K & Dandelion, chicory, garden sorrel & $4-5$ & $2-4$ \\
S & Fodder radish, dyer's woad, rape & $0.4-0.6$ & $0.1-0.4$ \\
B & Dyer's woad, salad burnet, stinging nettle & $40-50$ & $20-40$ \\
\hline
\end{tabular}

\section{Figures}
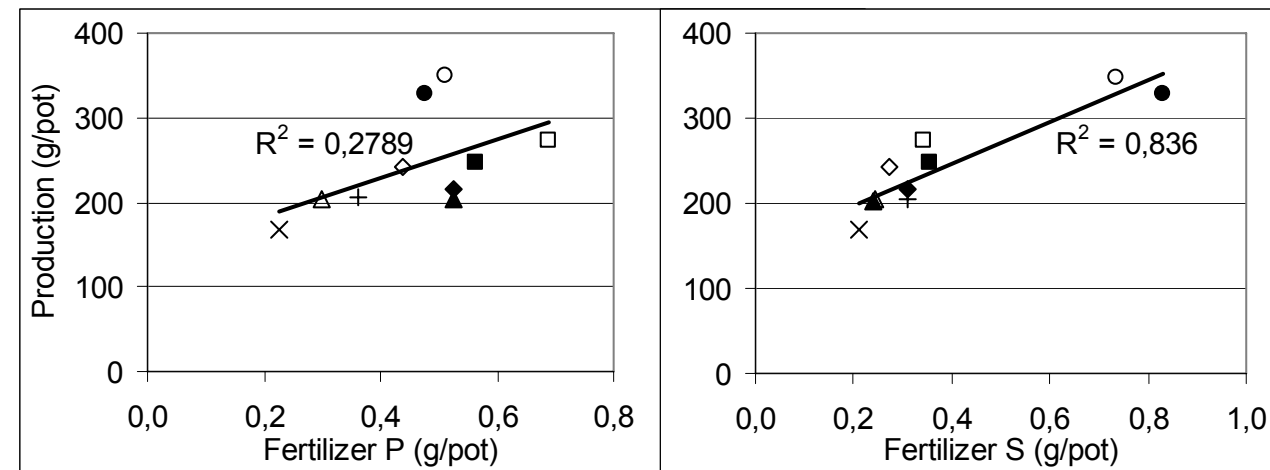

O Fodder radish

- Dyer's woad

$\square$ Garden sorrel

- Dandelion

$\diamond$ Yellow lupin

- Phacelia

$\triangle$ Red clover

$\Delta$ Buckwheat

+ English plantain

$\times$ Salad burnet

Fig. 1. Effect of $\mathrm{P}$ and $\mathrm{S}$ applied with various green-manure crops (125 g dry matter per pot) on the production of kale. 


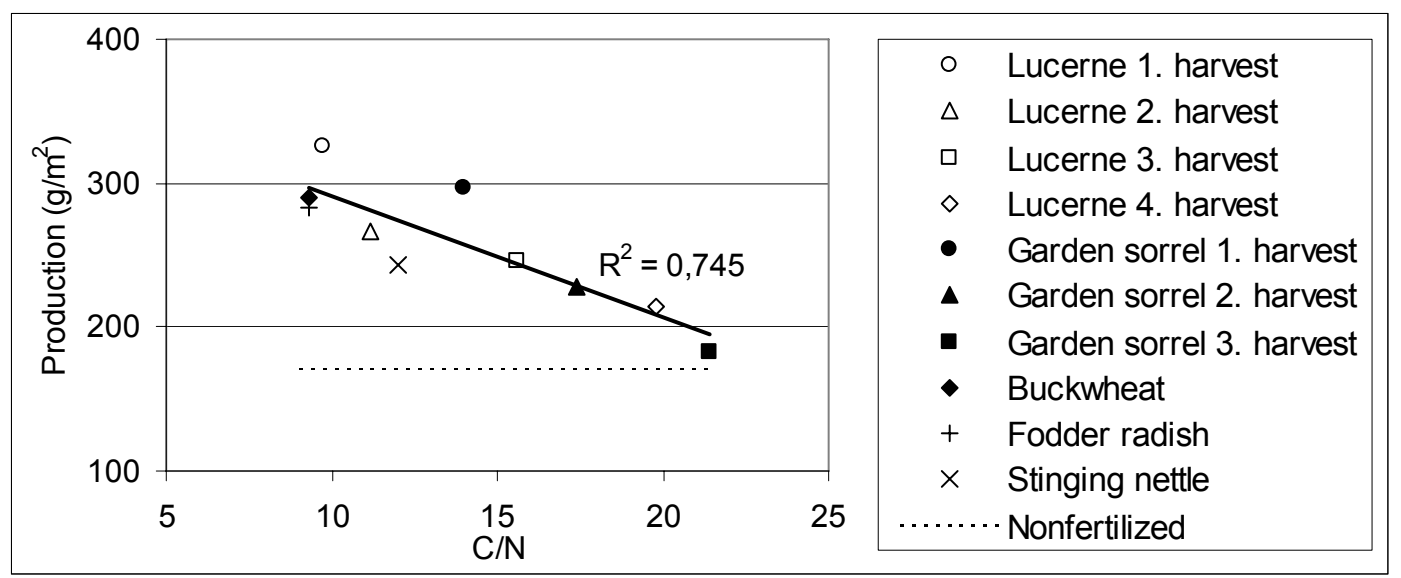

Fig. 2. Dry matter production of kale leaves in relation to $\mathrm{C} / \mathrm{N}$ ratios of applied green manure. The dotted line represents the production of non-fertilized kale plants.

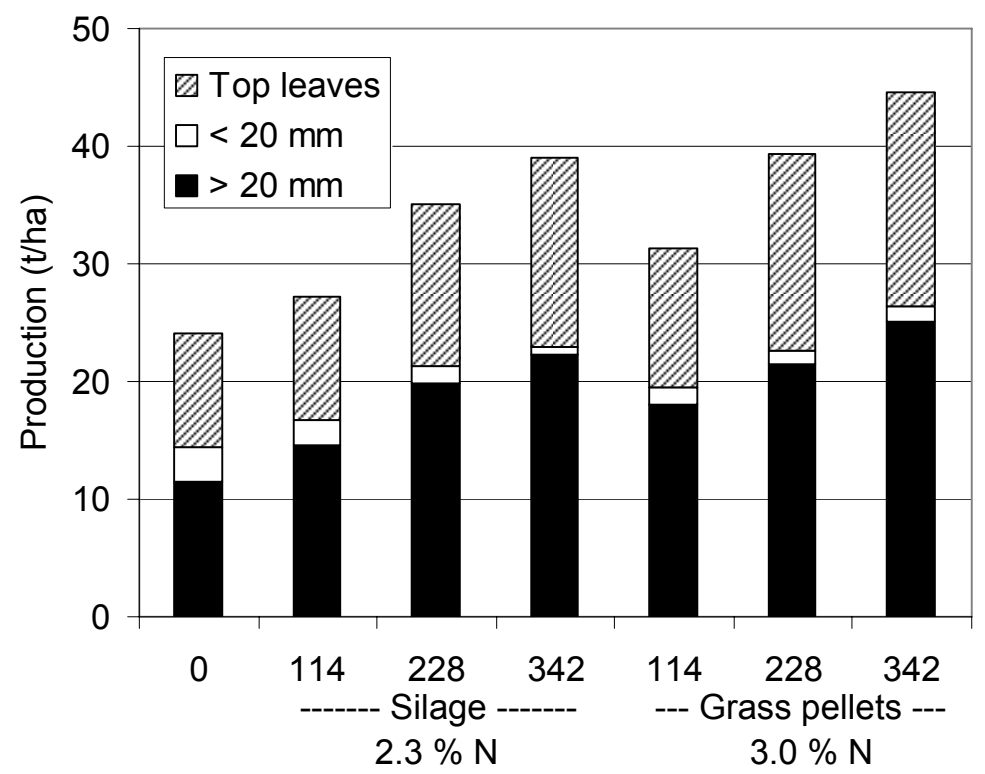

Fig. 3. Plant production of leeks in relation to $\mathrm{N}(\mathrm{kg}$ total $\mathrm{N}$ per ha) applied with silage $(\mathrm{C} / \mathrm{N}$ ratio 19$)$ and clover-grass pellets $(\mathrm{C} / \mathrm{N}$ ratio 14$)$. 
